\title{
Towards Phraseologism Formation and Terminologization in Scientific and Technical Texts
}

\author{
Darya A. Aripova*, and Irina S. Bashmakova \\ Irkutsk National Research Technical University, 664074, Lermontov Street, 83, Irkutsk, Russia
}

\begin{abstract}
The given research deals with the problem of phraseologism formation and further terminologization of such word-combinations as: Dutch slice-hip roof, Dymaxion House, Inhoff tank, dragon summer, cyclopean concrete, dragon tie, horse shoe curve, double Roman tile, etc. It is noted that object categorization takes place in man's consciousness. Once being used as a fixed wordcombination in professional text, the lexical unit may preserve the formed holistic meaning and can be transferred to the category "phraseologism". The three obligatory identification requirements for word-combination to be transferred to the category "phraseologism" have been defined. The phraseologism functions in the scientific and technical text have been determined.
\end{abstract}

\section{Introduction}

New fundamental researches in science make scholars rethink the dominant ideas about man and his place in the world. The deeper man's thought penetrates into various spheres of reality, the more complex and inexhaustible subject of the research is. The changes that happen expose a number of new problems for the community consciousness. The theories of natural languages are characterized by cyclicity, which determines the development of the scientific ideology of mankind generally. The periodic change forms the methodological foundations of linguistics, as well as the methodology of other branches of science [1]. The American physicist, historian, and philosopher of science T. Kuhn described such sort of dynamics as "paradigm shift" [2]. At present, we witness another change in the ideological paradigm in linguistics. In the mid-sixties and later many linguists spoke up for the metaphysical point of view [3, 4], according to which there was a strict distinction between the linguistic competence and the language use. Modern language studies are impossible without involving such concepts as intention, memory, action, semantic inference into the process of cognition [5]. Participating in acts of communication, man understands what other people say, and he himself generates statements. Man's aim is to understand thoughts expressed with language, where language is a sort of "storehouse" of knowledge. The study of knowledge used in the course of language communication is considered as one of the leading directions in cognitive science. The term "cognitive science" has been used since the mid-1970s to describe the sphere within which the processes of assimilation, accumulation and information used by a person are studied. Cognitive science is the science of knowledge and cognition, the science of the results of man's world perception and the people object-cognitive activity, accumulated in the form of meaningful and processed data that are somehow represented in our consciousness and constitute the basis of mental processes [6].

The excursus into the languages development is important as in the given article an attempt to analyze the processes of knowledge representation and its further information processing in man's mind when we deal with phraseologism formation and terminologization is undertaken. The purpose of the article is to prove that phraseologism is a competent concept expression means for man's perception when it is used in the scientific and technical text. The tasks to be solved are the following: to determine the obligatory identification requirements of phraseologisation of such word-combinations, like: Reno/Renault mattress, fishplate, plaster of Paris, dog-leg stair and their further transition to the category "term". The topicality of the article is due to the frequent use of the mentioned above word-combinations in scientific and technical texts. Consequently, the problems with the word-combinations understanding, translating into another language, and categorization occur. The novelty of the work is in the defining the identification requirements for phraseologism formation. Practical value of the research is characterized by the necessity and expediency of a comprehensive study of phraseologism functions in scientific and technical texts due to its categorical systemic properties, namely: a broad semantic basis that gives phraseologism the opportunity to correlate with numerous denotations, imagery, informative capacity, and connotation expression.

\section{Materials and methods}

The research materials are more than 200 fixed wordcombinations and idioms taken from phraseological and

* Corresponding author: aripovad@mail.ru 
technical dictionaries, technical books, and newspaper articles. The research is focused on phraseological identification method, the morphemic analysis, linguistic experiment method. Various aspects of phraseologism interpretation in discourse are considered by the method of comparative analysis.

\section{The main part}

At present time one can observe a continuous process of changing character of the scientific and technical texts due to the increasing use of lexical units of different types in them. Surprisingly, but the presentation in the scientific discourse of verily technical questions in modern scientific and technical literature occurs by increasing use of expressive units of complicated semantics such as phraseologisms. As there is a tendency to call any wordcombination as "phraseologism" and more, "idiom" nowadays, it is necessary to specify which definition of "phraseologism" is basic in this work. Phraseology as a branch of linguistics has a long history. In the Soviet Union, the emergence of phraseology as a linguistic discipline referred to the 40-th of the 20-th century and was associated with the name of V.V. Vinogradov, a wellknown Russian linguist, specialist in the Russian philology. It was the academician V.V. Vinogradov who first developed a synchronous classification of phraseological units (based on the Russian language) from the point of view of their semantic cohesion and outlined the ways of further phraseological units studying [7].

In the given article, phraseologism is defined as a fixed word-combination with a holistic meaning [8]. The terms: "fixed phrase" and "fixed word-combination" are used as fully interchangeable. According to A.V. Kunin's classification, "Achilles' heel" is a phraseologism, and more -idiom [8, ibid]. It is so as, firstly, it is a fixed wordcombination with holistic meaning, and secondly, it is a well-known idiom fixed in several dictionaries and it is widely used in fiction. What is the reason to use such lexical unit as Achilles' heel in texts? One answers that it is used for artistic expressiveness. It is taken for granted, phraseologisms and idioms are the means to achieve expressiveness, to create imaginative, ironic, or humorous effect, which are actively used in belles-lettres. No doubt, it is a true fact. Let's analyze the following sentences.

1) The Achilles' heel of X-ray laser turned out to lie in how tightly the beam can be focused. (X-rays expose blueprint for possible sleeping sickness drug) [9]

2) Over the last century, scientists have embraced the idea of mobilizing antitumor immune responses in patients with cancer. In the last decade, we have seen the rebirth of cancer immunotherapy and its validation in a series of high profile clinical trials following the discovery of several immune-regulatory receptors. Recent studies point toward the tumor mutational load and resulting neoantigen burden as being crucial to tumor cell recognition by the immune system, highlighting a potentially targetable Achilles' heel of cancer. In this review, we explore the key mechanisms that underpin the recognition of cancerous cells by the immune system and discuss how we may advance immunotherapeutic strategies to target the cancer mutanome to stimulate tumor-specific immune responses, ultimately, to improve the clinical outcome for patients with cancer [10].

Both extracts mentioned above are devoted to specific knowledge in medicine. When interpreting the first example, it becomes clear that, according to the author's opinion, the degree of the beam focus is a global problem, which practically excludes the possibility of using the Xray laser in future in medical practice. The laser inability to be used in practice is highlighted by the phraseologism “Achilles' heel". Achilles' heel is a weakness or vulnerability, which can lead to permanent destruction or downfall. In Greek mythology, the hero Achilles was killed after being struck in the heel, the only weak spot on his body. When a child, his mother held him by one heel to dip in the River Styx to make him invulnerable [11]. In the second example, "Achilles' heel" means that cancer, once thought to be incurable disease can be cured as it has its Achilles' heel. The problem is to identify this vulnerable spot of cancerous tumor and start the right treatment.

Was it possible for the authors of the articles to use other language units to describe the situation? It was. What is the explanation for their preference? Two more examples are given to clarify the reason.

1. Logical arithmetic. Arithmetic involving logical expressions is very useful in programming and in selection of variables. If logical arithmetic is unfamiliar to you, then persevere with it, because it will become clear how useful it is, once the penny has dropped. The key thing to understand is that logical expressions evaluate to either true or false (represented in R by TRUE or FALSE), and that R can coerce TRUE or FALSE into numerical values: 1 for TRUE and 0 for FALSE. Suppose that $\mathrm{x}$ is a sequence from 0 to 6 like this: $\mathrm{x}<-0: 6 \ldots[12: 25]$.

2. There is an enormous range of things that $\mathrm{R}$ can do, and one of the hardest parts of learning $\mathrm{R}$ is finding your way around. Likewise, there is no obvious order in which different people will want to learn the different components of the $\mathrm{R}$ language [12: 12].

"Once the penny has dropped" means a belated realization of something after a period of confusion or ignorance [13].

"Find one's way around (something)" means to discover a way to move to some place without getting lost [13].

Both units, once the penny has dropped and find one's way around are actively used idioms in fiction. But, the text under review is a technical one. It is devoted to programming. It seems when the author used the given idioms, his intention was to achieve a certain stylistic effect, a purposeful impact on the addressee, viz. to convince him that any complex phenomenon in the process of writing computer programmes can be understood, and applied. Thus, along with the inherent, universally recognized functions (communicative, cognitive and nominative), the phraseological units in the scientific and technical texts acquire new ones: pragmatic function, i.e. a targeted impact on the addressee and stylistic function, which helps to have a certain stylistic 
effect while maintaining the general content of the utterance.

For further analysis, it is necessary to specify the terms "discourse", "text", "scientific and technical text", "context". The literature on this issue is enormous. We choose the "text" definition which goes back to the works in the field of discourse and text by Van Dijk T. and Kintch W. $[14,15]$. This approach has the advantage over the others due to the detailed analysis of analytical tools. In macrostrategies and episodic models, the properties of the integer (discourse) and of individual linguistic means are fully represented. According to the authors' theory, discourse is a broader and more universal linguistic object which encompasses not only the language structure of speech, but it also includes the typical parameters of a communicative situation, characteristics of communicants, strategy of communication creating. Unlike discourse, text is a more specific and narrow phenomenon that does not go beyond the proper structural and semantic parameters of the speech product. In speech activity, communicants, depending on their role at a certain moment, move from discourse to text, and vice versa. The first way is the production of speech, the search of linguistic means to express the information which speaker / writer intends to send to his listener / reader, i.e. from discourse to text. The second way is actions of listener / reader. If an interpreter wishes to penetrate deeper into the meaning of a specific text, he obtains the necessary information with the help of discourse components $[14$, ibid]. Thus, text is a speech product. It consists of sentences which a speaker creates by selecting the language units and connecting them according to the grammar rules of the language in accordance with the communicative intentions. The utterance creation occurs on the basis of both linguistic and extra linguistic factors.

As we need the definition of scientific and technical text, we'll take into consideration one more text classification. The German translator A. Neubert offered to classify texts on the basis of their pragmatic orientation. His idea is based on the fact that the most important task of translation is to transfer the real impact of the original text to the reader so that the reader of the translated text version has the same pragmatic relations to the transmitted message as the author of the original text. According to the author's theory, the first type of texts is scientific and technical. Both the original text version and the translated one from this category have common goals based on common needs. Such texts have the highest degree of translatability from a pragmatic point of view. The second text type is texts of laws, socio-political literature, official orders, local information, entertainment materials, etc., exclusively intended for the audience of the original language. The third text type is fiction. Although the texts are created for the audience of the original language, they can also express universal needs. The degree of translatability depends on the text genre. The fourth text type is publications for foreign countries, intended for translation into another language and originally targeted at the audience of the target language. Such texts have a high degree of pragmatic translatability [16]. In the given article, the first text type (Neubert A. classification) is considered as the scientific and technical text. The scientific and technical text is used to express ideas of scientific research, theories, explanation of scientific facts, hypotheses, etc. The basis for the language design of scientific and technical texts is standardization, i.e. choice of specific clichés prescribed for definite communication conditions. The syntactic features of text include the syntactic completeness of utterance formulation, presence of analytical constructions, frequent use of fixed terms, mainly of the nominal character, connecting elements (conjunctions). So, we agreed on the working definitions of the following notions: phraseologism, text, discourse, scientific and technical text.

As it is accepted [16, ibid.], the main feature of the scientific and technical texts is an accurate, complete presentation of the material with a small number of expressive elements, which are inherent to fiction to convey emotional text constituent. However, as it was demonstrated above, with obvious stylistic remoteness from fiction, which is full of bright expressive means, the scientific and technical texts do not exclude the use of phraseologisms.

For further investigation, the obtained results of the linguistic experiment are necessary [17]. The question under discussion is whether the given fixed wordcombinations are perceived as phraseologisms with integral meaning by students, or they interpret them as unrelated components which are translated separately. The experiment was conducted at Irkutsk National Research Technical University, Institute of Linguistics and Intercultural Communication. The aim of the experiment was to test the students' ability to identify phraseologisms (without their usage context), to extract and apply extra linguistic information while specifying the units. And further, the students had to give the units translation. A total number of the students who took part in the experiment was 13. They all are the students who undergo the university programme "Translator in the professional sphere". At the first step of the experiment (the theoretical level), the students were explained the task of the forthcoming experiment. The definitions of "phraseologism" and "term" were differentiated. At the second step (the methodic level), the experiment procedure, and important instructions were given. At the third step (the empirical level), the students tried to do the task in limited time. The table with the task for students is presented (Table 1).

At the fourth step of the experiment (the analytical level), the results were summarized and discussed. The majority of students (11 of 13) didn't mark as phraseologisms the word-combinations like: backdoor, mouse potato, Raspberry Pi, garage (Taj) Mahal, plaster of Paris, dog-leg stair, Brussels carpet, fish plate, Reno/Renault mattress. These word-combinations were given in capital letter in the table in order not to give the hint to the students. In the column "STUDENT'S EXPLANATION OF THE WORD-COMBINATION" the future translators gave approximately equal interpretation, like: the name for a plate only for fish (fish plate); one more door of the house (back door); a pie with strawberry (strawberry pie); a carpet which was brought from Brussels (Brussels carpet), a mattress from Reno 
(Renault mattress); the house where the family Dymaxion lives (Dymaxion House). Several word-combinations, like: mouse potato; Garage Taj Mahal; plaster of Paris were not interpreted at all.

Table 1. What do the given fixed word-combinations mean?

\begin{tabular}{|c|c|c|c|c|}
\hline $\begin{array}{l}\text { Word } \\
\text { number }\end{array}$ & $\begin{array}{l}\text { Phraseolog } \\
\text { ism } \\
\text { (related } \\
\text { fixed } \\
\text { meaning) }\end{array}$ & $\begin{array}{l}\text { Word- } \\
\text { combin } \\
\text { ation } \\
\text { (unrela } \\
\text { ted } \\
\text { meanin } \\
\text { g) }\end{array}$ & Term & $\begin{array}{l}\text { Student } \\
\text { 's } \\
\text { explana } \\
\text { tion of } \\
\text { the } \\
\text { word- } \\
\text { combin } \\
\text { ation }\end{array}$ \\
\hline $\begin{array}{l}\text { 1. Sword of } \\
\text { Damocles }\end{array}$ & $v$ & & & \\
\hline 2. Fish plate & & $V$ & & \\
\hline $\begin{array}{l}\text { 3. Reno/Ren } \\
\text { ault mattress }\end{array}$ & & $\nu$ & & \\
\hline $\begin{array}{l}\text { 4. Dog-leg } \\
\text { stair }\end{array}$ & & $V$ & & \\
\hline $\begin{array}{l}\text { 5. Dymaxio } \\
\text { n House }\end{array}$ & & $\checkmark$ & & \\
\hline $\begin{array}{l}\text { 6. Plaster of } \\
\text { Paris }\end{array}$ & & $V$ & & \\
\hline $\begin{array}{l}\text { 7. Brussels } \\
\text { carpet }\end{array}$ & & $\checkmark$ & & \\
\hline $\begin{array}{l}\text { 8. Garage } \\
\text { Taj Mahal }\end{array}$ & & 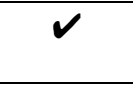 & & \\
\hline $\begin{array}{l}\text { 9. Raspberry } \\
\text { pi }\end{array}$ & & $\checkmark$ & & \\
\hline $\begin{array}{l}\text { 10. Mouse } \\
\text { potato }\end{array}$ & & $\checkmark$ & & \\
\hline $\begin{array}{l}11 . \\
\text { Backdoor }\end{array}$ & & $V$ & & \\
\hline $\begin{array}{l}\text { 12. Judas } \\
\text { kiss }\end{array}$ & $v$ & & & \\
\hline
\end{tabular}

As the fixed phrases from the table, which were not understood in the right way by the students, are important for our further analysis, their explanation taken from dictionaries is given.

1. fish plate/fishplate (railway) - fish plate is a metal or wooden plate that is bolted to the sides at the ends of two rails or beams, to join them. A fish plate does not have anything in common with the aquatic fish [18].

2.Reno/Renault mattress (architecture) - Reno mattresses and gabions consist of a galvanized steel wire mesh compartment basket with a rectangular mattress shape. The compartment or cells of the Reno mattress are of equal size and dimension and are filled with stone [19].

3.dog-leg stair (architecture) - A dog-leg stare is a configuration of stairs between two floors of a building, often a domestic building, in which a flight of stairs ascends to a half-landing before turning at a right angle and continuing upwards. The flights do not have to be equal, and frequently are not [19].

4.Dymaxion House (architecture) - The Dymaxion House was a futuristic dwelling, which was invented by the architect and practical philosopher R. Buckminister
Fuller. The word "Dymaxion," which combines the words dynamic, maximum and tension, was coined by Fuller himself. In 1920 Fuller wished to build a sustainable autonomous single family dwelling, a sort of future living machine. Although never built, the Dymaxion's design displayed forward-thinking and influential innovations in prefabrication and sustainability. Not only would the house have been exemplary in its self-sufficiency, but it also could have been mass-produced, flat-packaged and shipped throughout the world [19].

5.Plaster of Paris (architecture) - quick-setting gypsum plaster consisted of fine white powder which hardens when it is moistened and allowed to dry. It is known since ancient times. Plaster of Paris got its name thanks to its special preparation from the gypsum, found near Paris [19].

6.Brussels carpet (architecture) - type of machinemade floor covering with the loops of the pile uncut. All colours are brought above the foundation in loops, as needed, to produce the pattern. It was originated in or near Brussels. This technique became fashionable in the first half of the 19th century. Brussels carpets have been made in many places [19].

7. Garage (Taj) Mahal (construction and architecture) - a massive construction for work and rest with its sustainable materials and small footprint; this building is also an example of care for local sites and environment [19].

8. Raspberry Pi (cybernetics) - mini-computer for hobbyists and budding programmers [20].

9. mouse potato (cybernetics) - a person who spends large amounts of leisure or working time operating a computer [20].

10. backdoor (cybernetics) - a means to access a computer system or encrypted data that bypasses the system's customary security mechanisms [20].

Why couldn't the students translate the majority of the given word-combinations? The first reason is in their uncertainty that such phrases can have a holistic meaning. The students interpreted each word separately, but not as integer. The second reason is the lack of usage context. The third reason is the wrong usage of associations dealt with the objects. A different concept was formed in their mind, far from the veritable. So, the question is whether the given word-combinations are phraseologisms or not? According to A. V. Kunin's three obligatory phraseologism identification markers: sustainability; the impossibility of constructing by the generating model (reproducibility); fixation by at least one dictionary, they are. The essence of phraseologization of such units is in the process of emergence of phraseologism properties in them. We came to this conclusion having taken into consideration two factors: sustainability and reproducibility. Sustainability is related to the idea of invariance. Phraseological sustainability is a range of various aspects which cause phraseologism reproducibility in the finished form and its identity in casual and occasional changes. Phraseological sustainability is characterized by different levels:

- the maximum level of sustainability (adverbial phraseologisms, phraseological intensifiers, substantive phraseologisms with coherent structure); 
- the high level of sustainability (archaisms, proverbs and sayings as they have expressive reinterpretation in their semantics, or meaning compression);

- the low level of sustainability (partially integral meaning) [8].

As it was already mentioned above, phraseologism occurs when at least two significant words are involved in its formation, and they turn out to be semantically transformed to such a degree that they completely or partially lose their own lexical meaning. Between the high and low levels of semantic integrity there is a continuous chain of transition links, reflecting gradual convergence of the phraseologism component with the word, and the phraseologism - with the phrase itself. The phraseologism meaning integrity is achieved by full or partial reconsideration, deactualization of the components. Deactualization is semantic word transformation into phraseologism integral part, which becomes its constituent. As a result of semantic transformation, the components, as a rule, do not convey their meaning content (when they are used separately). To prove the previous conclusion, let's return to the mentioned above word-combinations or as we categorized them "phraseologisms", and try to analyze their use in the contexts.

\section{Fish Plate.}

Weld - When \& Why Is It Used? The failure analysis of fish-tail plate can be seen, one of the most important reasons for the cracks is the interaction between the rail and the fishplate. So, how to minimize the impact of this effect? It's a problem that is still to be solved. Besides, in recent years, when someone study the crack of the steel rail bolt and then notice the effect of the fishplate on the steel plate, find it can use the supporting form of the inclined plane of the fishplate, the wedge type supports can make the vertical tensile to the steel rail waist, this stress increases the production of the steel rail bolt crack. Therefore, it is recommended to use the hinged support structure widely used in the United States. At the same time, only the fishplate and the steel rail are considered as an inseparable system, study the interaction between them, it can ensure that the whole line has good connections, improve the safety of line operation [21].

\section{Raspberry Pi.}

The Raspberry Pi 3 Model B looks identical to the Pi $2 \mathrm{~B}$ at first glance. It is the same size and has much of the same components on board. So what is the difference? The new Pi 3 brings more processing power and on-board connectivity, saving you time with the development of your applications. Perfect for your Internet of Things (IoT) designs [22].

\section{Plaster of Paris}

No other object is as closely associated with the branch of orthopaedics as Plaster of Paris or POP as we commonly call it. Orthopaedicians have been associated with Plaster of Paris just like cardiologists with ECG and the plastic surgeons with Humby's knife. Its use is ubiquitous and we put it to such a myriad of uses that the list is endless. Plaster of Paris or calcium sulphate has found other uses as well. It has been used as bone graft substitute and to fill up bone defects. It has been used in spinal surgery as a bone graft substitute. POP is also being investigated as an antibiotic delivery mechanism [23].

No doubt, the given examples with Plaster of Paris, Raspberry Pi, Fish Plate completely prove the idea to categorize them as "phraseologisms" on the reason they are used and interpreted as sustainable wordcombinations with a holistic meaning. They have their holistic meaning only on condition that they are used together in a fixed form in a definite professional context. Exactly the usage context will be the key signal to such lexical units interpretation, considering them as phraseologisms. Nevertheless, this conclusion is obvious within the structural paradigm framework. In the cognitive paradigm, one of the main tasks is the study of semantic and cognitive properties of such sort of units and their representation in speaker's consciousness. Due to this approach, linguists take into account the information coded in phraseologisms. Cognitive semantics proceeds from meaning understanding based on the concepts representation that determines the characteristics of categorization, expressed in man's perception. Till now, there is a point of view (Amosova, Dobrovolskiy, Baranov) $[24,25]$ in phraseology that all phraseologism components have equal parts in its formation. Nevertheless, when we deal with idioms with proper name, it is possible to make more radical conclusion, viz. to acknowledge cognitive center, the center around which specific mythological knowledge is organized [26]. Proper names in idioms, like: Sword of Damocles, Judas kiss from the students' experiment mentioned above is that magic point where illocution and proposition are in one. And more, the proper name, being the cognitive center of the idiom, irradiates its symbolic meaning on the other components. For this research, more than 200 fixed combinations taken from different dictionaries were analyzed. The following categories were distinguished (based on literature on architecture) [19, 27].

Category 1. Terms with the concept "Proper name":

Brinell hardness, Brussels carpet, Buffalo box, Byzantine arch, Cumberland house, Danish knot, double Flemish bond, Diocletian window, double Roman tile, Douglas fir, Oregon pine, Durham fitting, Dutch door, Dutch roof, Dutch gambrel roof, Dutch shutter, Dutch slice-hip roof, Dymaxion House, Inhoff tank, Reno/Renault matress, Saint Andrew's cross, Poisson's ratio, etc.

Category 2. Terms with the concept "Animal and plant world":

air cock, bull-point, bull's-eye, butterfly hinge, butterfly wall tie, butterfly roof, clover leaf, catwalk, dogleg stair, crane boom, curb cock, cyclopean concrete, drop elbow, dead leaf, dead man anchor, dog-ear, dogtooth frieze, dogtooth, tooth ornament, dragon style, dragon summer, dragon tie, horse shoe curve, kangaroo tower crane, knee roof, white elephant, lamella roof, swallowtail, monkey's tail, agitator body, etc.

Category 3. Terms with the concept "Household items and things for man's everyday usage":

diamond pattern, diamond slate, double ax, drainage envelope, drawer slide, drum trap, accordion door, lancet arch, adjustable wrench, adopted street, airbrush, air 
pocket, knot garden, scissors junction, scissor arch, kokoshnik-dome, etc.

Having analyzed the given examples, we came to the conclusion that the hypothesis about the cognitive center is confirmed in the first highlighted category. Anthroponym or toponym is the point where the proposition and illocution are expressed in the proper name (Byzantine, Brussels, Brinell, Douglas, Dymaxion, Andrew, Poisson). To illustrate it, the explanation of Reno mattresses is given. Reno mattresses in architecture and construction is a stone laying, consisting of stacked in a certain order stones or bricks. The main goal of laying is to make the monolithic structure by stacking the stones of each upper row so that the vertical seams between them do not coincide with the vertical seams between the stones of the lower row. It is believed that such a structure was first used to eliminate the consequences of the flood of the river Reno near the city of Bologna (Italy) in 1893. Since that time for builders all over the world Reno mattresses is a special type of stone laying [19].

But, phraseologism meaning is not the concept 'gripped' by conventionally determined scheme of interpretation. Undoubtedly, in any particular case it is possible to define the meaning, which consolidates participants' communication. But this meaning is only a point to start further discoveries in proper name infinite content. The proper name in such units like Brussels carpet, Buffalo box, Byzantine arch, Cumberland house, Danish knot, double Flemish bond, Diocletian window, etc. is like a stone thrown into the water which forms many circles on the water surface. Such figurative representation is the core of phraseologism perception. While interacting, people understand each other by this "core". Excessiveness is absolutely necessary condition for phraseologisms understanding. References to their sociolinguistic source will always be excessive as they reproduce the information, already known from previous usage. In the case of phraseologisms with proper names, the first indicator is their link with the discourse of a definite type. In this connection, another problem occurs. Unit symbolic meaning is still arguable in cognitive linguistics.

Man's world perception, thinking, and understanding processes are the most complex forms of human interaction with the surrounding reality. Intellection is indirect knowledge of objects, phenomena, and events of material world. Comprehending the obtained knowledge, a man reveals not only its objective content, but transforms the previously disconnected parts into a system, determines the cause-consequence events relations known to him, including the comprehended fragment in a generalized world representation. The complex phenomenon "understanding" is one of the man's essences, which is responsible for man's opinion formation, judgments and ideas. This phenomenon has both cognitive and evaluative functions. But, man's memory can identify inaccurately, incorrectly, or wittingly false mental notions. The reason is that the studied mental activity and its event objects are located at different points on the time axis. The impossibility of determining if reminiscence is false or true is explained by inaccessibility of necessary information and the details which were formed in the past. As a result of the event reconstruction some part of information is lost and forgotten, then, is thought out, replaced by fantasies and potentially possible images correlated with a certain situation in the past [28]. It works in many cases but not with phraseologisms with proper names (Category 1).

As the considered above fixed units have been defined as "phraseologisms", the problem of their terminologization must be solved. Due to the fact that phraseology links up with terminology in terms of the parameters of sustainability and reproducibility, we investigated the points of links between phraseology and terminology. "Term" is a word or word combination of a special (scientific, technical, military, etc.) language, created (accepted, borrowed, etc.) for the precise expression of special concepts and designation of special subjects [29: 216]. Terms are classified into general scientific and technical (terms which are used in several sectors in science and technology); branch terms (terms which are used only in one knowledge field); narrowly specialized terms (terms which are specific to any specialty of the industry). Terms differ in their structure: simple (single word), complex (two words written together or with a hyphen), word-combinations (several components, words). As terms are nominative units of special concepts of various activities, they mark scientific and technical register of messages. Applying the procedure of the morphemic analysis of wordcombinations core components, the following parameters of multicomponent term formation are determined:

- use of productive word formation: word compounding, suffixation, conversion (e.g. fishplate, kokoshnik-dome, airbrush, bull-point, dogtooth);

- unit with advance predictability, explicitly represented meaning at the content plan level (kangaroo tower crane, oil spill, adjustable wrench);

- word-building models similar to ready-made phraseologism samples, which ensure the predictability of the term (to drop out of the picture, to be on the ball, the sea bee).

The essence of multicomponent terms is in the integrity concept, consequent sustainability of lexicosemantic structure. As a rule, when once fixed, component reproducibility and component replacing are impossible. Any term has a high degree of sustainability with a monosemantic attribute.

So, taking into consideration three main indicators: sustainability, reproducibility, fixation in a dictionary, we can define word-combinations, like: air cock, cookie cutter, bull-point, bull's-eye, butterfly hinge, butterfly wall tie, butterfly roof, clover leaf, etc. as both phraseologisms and terms. Phraseologism sustainability can be interpreted at the level of idiomaticity (the Achilles' heel), and the term sustainability can be presented at level of nominativeness (Buffalo box). It must be admitted, that the question whether any phraseologism can function as term in the scientific and technical texts is still open and needs further thorough linguistic investigations. To observe such phraseologisms function, the following examples are given.

1 .... One might even say that in terms of presentation, form-based codes are to conventional codes as compact as 
development is to sprawl. But part of the explanation for this lies in the fact that conventional codes have often been around for decades, and have suffered through numerous rounds of amendments and modifications, inflicted by many hands. Over time, they have become multi-layered and increasingly comlex. Rarely do we see an appropriately funded effort to re-codify an existing code from top to bottom. On the other hand, form-based codes - a recent phenomenon - arrive bright and shiny off the assembly line and cut from the same cloth. It will take some time to see if they age gracefully and how easily they are capable of accepting changes [30].

2."Roberto Mancini and Sir Alex Ferguson are cut from the same cloth" [31].

3. "Trump's meeting with Putin shows two men cut from the same cloth"

...As they leaned deeply towards one another in Hamburg, it was all too easy to see and hear the similarities between Donald Trump and Vladimir Putin. Trump said it was "an honor" to be with Putin, who gushed that he was "delighted to meet" Trump... [32] [33].

Cut from the same cloth - very similar to each other

Analyzing the phraseologism use in the given contexts, one can admit that in spite of text differences in genre, its general meaning is constant. The authors' intention was to focus on characteristic features, attitudes, or behaviour similarities of persons or objects (e.g. 1 - the form-based codes, e.g. 2 - an Italian football manager and a Scottish former football manager, e.g. 3 - presidents of two countries). The phraseologism cut from the same cloth fulfills its inherent function, viz. it intensifies expression.

There are many scientific works devoted to the question whether word-combinations like: white elephant, lamella roof, swallowtail, etc. should be considered as phraseologisms [9, 34]. The linguists noted that active phraseologization of the word-combinations under discussion in technical spheres is related to the processes of synonymy, polysemy, with formation of metaphorical and metonymic meanings. Besides, one can observe an interesting phenomenon of phraseological unit terminologization in the scientific and technical sphere. In this process, phraseologism, besides pragmatic and stylistic functions, mentioned in the beginning of the research, acquires additional meaning. As term, it is endowed with a function to allocate information; the axiological function; the function of storage and professional conceptual knowledge transfer; a function to fill in conceptual lacuna; the text-forming function verbalized in the form of discursive markers [34].

\section{Results}

1. One of the results of understanding is meaning presentation in episodic type of people's memory in the form of concept. There is no presentation, included in people's conscience as a result of speech activity, which can be vanished untraceably.

2. In man's consciousness the surrounding reality is categorized.
3. Sustainability, reproducibility, and fixation in a dictionary are the three basic identification markers if to refer the word-combinations, like: curb cock, cyclopean concrete, drop elbow, dead leaf, etc., to the category "phraseologism". The mentioned word-combinations can be called phraseologisms only in professional contexts when they denote one specific meaning.

4. In newly formed phraseologisms there is a fixed set of attributes which remains unchanged. The used names of things, persons, animals, and plants preserve in their semantics a set of associations connected with the real or imaginary image of them, and this information is enough to man's mind to be "processed" and understood.

5. Endowed with the nominative function, phraseologism can act as term in scientific and technical texts. Along with its main functions: nominative, cognitive, communicative, phraseologism acquires new ones. They are: the function to allocate information; the axiological function; storage and professional conceptual knowledge transfer function; the function to fill in conceptual lacuna; the text-forming function which is verbalized in the form of discursive markers.

6. Phraseologism is a competent concept expression means when it is used in scientific and technical text.

7. Phraseologism terminologization in scientific and technical texts is a unique phenomenon that must be subjected to further profound scientific research.

8. Term relative sustainability is a result of coherence. Being fixed as a component in the unit it has no semantic change. It has constant feature of a definite object. Sustainability is obtained on the sema-level, the nomination type is direct.

\section{Discussion}

1. Noting that the word-combinations, like: butterfly roof, catwalk, Dymaxion House, egg and dart obtain the status "phraseologism" only in specific professional context, differences between the context of functioning and the context of generation should be solved.

2 . The issues of obtaining, encoding, storing, and transferring information are relevant when dealing with the word-combination under discussion. It is necessary to study the mechanisms of transformation of sensory and mental categories into linguistic structures. When new phraseologism is formed, image-symbols play an important role in the process of processing information. It is necessary to identify those ways of moving from mental categories to linguistic structures, to determine the correspondence between them and to describe these phenomena from linguistic point of view.

2. It seems, that denotate-symbol role in the wordcombinations under investigation (insects, animals, historical personalities, etc.) is not to describe the "world of actions" (more often people do not remember the information relating to a particular person, time, thing, action), but to remind or refresh it in man's imagination. Image selection has been implemented by centuries by metaphorical transfer on the base of associative representations. Nonetheless, linguists will have to analyze at least two problems on this issue: the process of 
symbol "ingoing" into metaphor, and symbol meaning acquisition by the image, comprised by phraseologisms of the type under discussion [35].

3. Man's "Understanding" is due to the correlation of the specifics of discourse with that niche that is opened to express a characteristic meaning, i.e. "single in general" is indicated. The problem what "general" and "single" are in the word-combinations under consideration should be investigated.

\section{References}

1. V. de Paiva, Electronic Notes in Theoretical Computer Science ScienceDirect 269, 83-94 (2011)

2. T.S. Kuhn, The structure of scientific revolutions (Chicago University Press, Chicago, 1970)

3. W. Quine, Word and object (MIT Press, Cambridge, 1960)

4. B. Russell, History of Western philosophy (Routledge, London, UK, 2004)

5. J. Tamminen, M.H. Davis, K. Rastle, Cognitive Psychology 79, 1-39 (2015)

6. A. Clarke, K.I. Taylor, B. Devereux, B. Randall, L.K. Tyler, Cereb Cortex. 23(1), 187-197 (2013)

7. V.V. Vinogradov, Selecta. Lexicology and lexicography (Nauka, Moscow, 1977)

8. A.V. Kunin, A course on modern English phraseology (Vysshaya shkola, Moscow, 1986)

9. A. Cowie, Phraseology: theory, analysis, and applications (Clarendon Press, Oxford, 1998)

10. K. Joshi, B.M. Chain, K.S. Peggs, S.A. Quezada, Cold Spring Harb Perspect Med. 8 (1), 2 (2017)

11. A.V. Kunin, English-Russian phraseological dictionary (Russkiy Yazyk, Moscow, 1984)

12. M.J. Crawley, The R Book (John Wiley and Sons Ltd., Chichester, UK, 2013)

13. The Free Dictionary by Farlex, URL: https://idioms.thefreedictionary.com/the+penny+dro ps (date of access: 10.05.18).

14. T.A. van Dijk, Discourse as structure and process: Discourse Studies: A Multidisciplinary Introduction (Sage Publications, London, 1997)

15. W. Kintsch, The Representation of meaning in memory (Erlbaum, Hillsdale, New York, 1974)

16. A. Neubert, Questions of the theory of translation in Foreign Linguistics, 185-202 (1978)

17. I.A. Baudouin de Courtenay, Selecta on general linguistics (USSR Academy of Sciences, Moscow, 1963)

18. A.V. Kosmin, V.V. Kosmin, Russian-English railway dictionary (Marshrut, Moscow, 2004)

19. C.M. Harris, Dictionary of architecture and construction (McGraw-Hill Inc., New York, 2006)

20. I.L. Mostitskiy, English-Russian encyclopedic dictionary of modern electronic engineering and programming: audio, video, $T V$, radio, computers, internet, telecommunication, etc. (Triumph, Moscow, 2004)

21. Advanced Technology Leading Quality, Rail joint, ZX Steel Group, URL: http://www.zxsteelrail.com/productDetail_33/?gclid $=$ Cj0KCQjwodrXBRCzARIsAIU59TI9cDKHclkdG slLtmDUijU7puYDhGe31kh-

HZfh5ZTZ1XNF2PXE3caAlKJEALw_wcB (date of access: 11.05.18).

22. New and interesting finds on Amazon, Raspberry Pi 3 Model $B$ Motherboard, Amazon, URL: https://www.amazon.com/Raspberry-PiRASPBERRYPI3-MODB-1GB-Model-

Motherboard/dp/B01CD5VC92 (date of access: 11.05.18).

23. H. Sharma, D. Prabu, Plaster of Paris: Past, present and future, Clin Orthop. 4(3), (2013), URL: https://www.ncbi.nlm.nih.gov/pmc/articles/PMC388 0430/ (date of access: 11.05.18).

24. N.N. Amosova, Fundamentals of English phraseology (Leningrad University, Leningrad, 1963)

25. A.N. Baranov, D.O. Dobrovolskiy, Fundamentals of phraseology (Flinta, Moscow, 2013)

26. I.S. Bashmakova, Phraseological units in the aspect of translation (Irkutsk National Research Technical University, Irkutsk, 2017)

27. A.S. Partina, Architectural terms. Illustrated dictionary (Stroyizdat, Moscow, 1994)

28. D.A. Aripova, Bulletin of Kemerovo state university 2(58), 176-179 (2014)

29. J.B. Walmsley, Linguistic terminology. Encyclopedia of language and linguistics (Elsevier Ltd., Oxford, 2006)

30. B. Abelow, H.M. Ballon, S.R. Beckwith and others, Form-based codes in New Jersey. Issues and opportunities (Regional Plan Association, New York, 2010)

31. P. Wilson, Roberto Mancini and Sir Alex Ferguson are cut from the same cloth, The Guardian (2012), URL:

https://www.theguardian.com/football/blog/2012/ma y/19/roberto-mancini-sir-alex-ferguson (date of access: 11.05.18).

32. R. Wolffe, Putin denies US election interference in meeting with Trump, officials say - as it happened, The Guardian (2017), URL: https://www.theguardian.com/world/live/2017/jul/07 /g20-summit-trump-and-putin-to-meet-as-worldleaders-gather-in-hamburg-live-coverage (date of access: 12.05.18).

33. Oxford English Dictionary (OUP, Oxford, 1984)

34. T.R. Donat, M.A. Candel-Mora, Procedia - Social and Behavioral Sciences 212, 250-255 (2015)

35. N.D. Arutyunova, Types of linguistic meanings: evaluation, events, facts (Nauka, Moscow, 1988) 